\title{
GROWTH AND NUTRITION OF Paratecoma peroba SEEDLINGS IN DIFFERENT TUBE VOLUMES AND CONTROLLED-RELEASE FERTILIZERS
}

\author{
Thais Arão Feletti ${ }^{1}$, Emanuel França Araújo ${ }^{2 *}$, Elzimar de Oliveira Gonçalves ${ }^{2}$, \\ Thamara Arão Feletti ${ }^{3}$, Aline Ramalho dos Santos ${ }^{2}$ Elbya Leão Gibson ${ }^{2}$ \\ ${ }^{1}$ Post-graduate, Regional University of Blumenau, Blumenau, Santa Catarina State, Brazil. thais_feletti@hotmail.com. \\ ${ }^{2}$ Post-graduate, Federal University of Espírito Santo, Department of Forest and Wood Sciences, Campus Jerônimo Monteiro, State \\ of Espírito Santo, Brazil. emanuelfa.bj@hotmail.com*; elzimar.goncalves@ufes.br; alineramalho13@hotmail.com; \\ elbyagibson@hotmail.com \\ ${ }^{2}$ Post-graduate, State University od Feira de Santana, Feira de Santana, Bahia State, Brazil. thamarafeletti8@gmail.com.
}

Received for publication: 22/02/2019 - Accepted for publication: 23/08/2019

\begin{abstract}
Resumo
Crescimento e nutrição de mudas de Paratecoma peroba em função do volume do tubete e fertilizante de liberação controlada. A Paratecoma peroba é espécie florestal nativa de grande interesse econômico e ecológico, atualmente está em risco de extinção pela exploração seletiva e ilegal, entretanto não há parâmetros estabelecidos para a produção de mudas da espécie. Desta forma, objetivou-se com este trabalho analisar o crescimento e balanço nutricional de mudas de P. peroba cultivadas em diferentes volumes de tubetes e doses de fertilizante de liberação controlada. Foram testados três volumes de tubetes $\left(120,180\right.$ e $\left.280 \mathrm{~cm}^{3}\right)$ e quatro doses $\mathrm{FLC}\left(0,2,5 ; 5\right.$ e $\left.7,5 \mathrm{~kg} \mathrm{~m}^{-3}\right)$ mais uma adubação mineral convencional (AC), conforme indicação na literatura para espécies florestais nativas, dispostos em delineamento inteiramente casualisado em esquema fatorial de $3 \times 5$, com quatro repetições compostas por 16 mudas. Após 180 dias foi analisada a porcentagem de sobrevivência, as variáveis de crescimento, índices do sistema integrado de diagnose e recomendação e do índice de balanço nutricional médio das mudas. Com base na matéria seca total e no índice de balanço nutricional médio, a combinação, tubete de $280 \mathrm{~cm}^{3}$ associada a dose $7,5 \mathrm{~kg} \mathrm{~m}^{-3}$ de FLC mostrou-se a mais adequada na produção de mudas de $P$. peroba.

Palavras-chave: peroba-amarela; viveiros florestais; recipientes; adubação; DRIS.
\end{abstract}

\section{Abstract}

Paratecoma peroba is a native forest species of great economic and ecological interest, currently at risk of extinction from selective and illegal exploitation; however, there are no established parameters for the production of seedlings of this species. The objective of this study was to analyze the growth and nutritional balance of $P$. peroba seedlings grown in polypropylene tubes of different sizes with variable doses of controlled-release fertilizer (CRF). Three volumes of tubes $\left(120,180\right.$, and $\left.280 \mathrm{~cm}^{3}\right)$, four CRF doses $\left(0,2.5,5\right.$, and $\left.7.5 \mathrm{~kg} \mathrm{~m}^{-3}\right)$, and a conventional mineral fertilizer (CF) were tested as indicated in the literature for native forest species: arranged in a completely randomized design in a $3 \times 5$ factorial scheme, with four replicates composed of 16 seedlings. After 180 days, the percentage of survival, growth variables, indices of the diagnosis and recommendation integrated system, and the average nutrient balance index of the seedlings were analyzed. Based on the total dry matter and the mean nutritional balance index, the combination of a $280 \mathrm{~cm}^{3}$ tube with a $7.5 \mathrm{~kg} \mathrm{~m}^{-3} \mathrm{CRF}$ dose was the most effective in the production of $P$. peroba seedlings.

Keywords: peroba-amarela; forest nurseries; containers; fertilizing; DRIS.

\section{INTRODUCTION}

Paratecoma peroba (Record and Mell) Kuhlm, popularly known as peroba-amarela, peroba-docampo e ipê-peroba is a tree species belonging to the family Bignoniaceae. These large trees can reach up to $40 \mathrm{~m}$ in height with a diameter of 40 to 80 centimeters (LORENZI, 2009). P. peroba is endemic to the Atlantic Forest and naturally occurs within the limited area south of Bahia, east of Minas Gerais, Espírito Santo, and north of Rio de Janeiro. Currently endangered due to intense exploitation, the species has great ecological and economic importance because of its natural beauty and wood quality. There are an estimated 8,500 adult individuals of $P$. peroba in nature (CNCFLORA, 2012).

In addition to the difficulty in finding matrices, the species has irregular seed production, with years of intense production followed by years of scarcity (LINS; NASCIMENTO, 2010). The seeds are recalcitrant, and the plants grow slowly in the nursery phase, taking around 6 to 8 months for seedling production (LORENZI, 2009). Therefore, there is a need to develop alternative and/or improved P. peroba propagation techniques to increase the availability of seedlings for species conservation projects.

Modern nurseries have gradually adopted the use of commercial substrates and polypropylene tubes, including biodegradable tubes such as Ellepot, in place of substrates composed of subsurface soil

FLORESTA, Curitiba, PR, v. 50, n. 3, p. 1613 - 1622, jul/set 2020.

Feletti, T. A. et.al.

ISSN eletrônico 1982-4688

DOI: $10.5380 /$ rf.v50 i3. 65120 
samples and organic matter (ARAÚJO et al., 2016), and plastic bags (GASPARIN et al., 2015), respectively.

Polypropylene tubes have advantages over plastic bags, such as the possibility of reuse, better formation of the seedling root system, lower substrate consumption, higher number of seedlings per area, and better handling, transport, and planting of seedlings (GONÇALVES et al., 2005). Despite these advantages, using the incorrect tube volume can result in deformation of the root system due to space limitations, with possible consequences on its performance in the field (JUNIOR et al., 2013).

Fertilizer application is required when using commercial substrates, which can result in increased production costs. Controlled-release fertilizers (CRFs) are polymer-coated fertilizers that release active nutrients in a controlled manner, extend the duration of nutrient release, and meets he metabolic needs of the plant (IRFAN et al., 2018). The use of CRFs in nurseries provides several benefits, such as reduced production costs, culture cycles, and labor.

Some techniques can illuminate the relationship between nutrients applied through fertilization and their assimilation by plants. Chemical analysis of the leaves, when well-interpreted, can be a useful tool for correcting nutritional deficiencies and imbalances in plants. In this sense, the Diagnosis and Recommendation Integrated System (DRIS) is used to interpret foliar chemical analysis. In short, the DRIS uses multiple relationships between nutrients and integrates them in a series of indices, thus taking into account the relationships and interactions between nutrients instead of the absolute and isolated concentration of each. The lower the negative DRIS index, the more nutrient-deficient the plant will be, and the higher the positive DRIS index, the more nutrient-rich the plant will be (WALWORTH et al.,1986).

Thus, the aim of this study was to analyze the growth and nutrition of $P$. peroba seedlings produced in different tube volumes and $\mathrm{CRF}$ doses. Therefore, we tested the following hypotheses: (i) the volume of the tube influences the growth of $P$. peroba seedlings; (ii) higher CRF doses enhance the growth and nutritional quality of seedlings of this species.

\section{MATERIAL AND METHODS}

The experiment was conducted in a university forest nursery located in the experimental area of the Department of Forest and Wood Sciences belonging to the Federal University of Espírito Santo (DCFMCCA-UFES) in Jerônimo Monteiro, south of the state of Espírito Santo, from July 2017 to November 2017. The experimental area has a latitude of $20^{\circ} 47^{\prime} \mathrm{S}$, a longitude of $41^{\circ} 23^{\prime} \mathrm{W}$, and an altitude of $120 \mathrm{~m}$. The region's climate is classified as Cwa (dry winter and rainy summer) by Köppen (1948).

The seeds were obtained from fruits selected from 20 matrix P. peroba trees, harvested in Reserva Natural da Vale S.A., in the municipality of Linhares, in ES, at $19^{\circ} 23^{\prime} \mathrm{S}$ and $40^{\circ} 04^{\prime} \mathrm{W}$ with an altitude of 43 $\mathrm{m}$. The project was registered in SisGen for access to the genetic heritage (A796E13). After beneficiation, the largest and most vigorous seeds were selected. No pre-germination treatments were used on the seeds.

The experimental design was completely randomized in a $3 \times 5$ factorial scheme, consisting of three volumes of tubes $\left(120,180\right.$, and $\left.280 \mathrm{~cm}^{3}\right)$, and four doses of CRF (Basacote ${ }^{\circledR}$ Mini $6 \mathrm{M}$ (0 (control), $2.5,5.0$, and 7.5) plus a conventional mineral fertilizer (CF), with four replications. Each replicate consisted of 16 seedlings, totaling 960 experimental units and 64 units per treatment.

Conventional fertilization, proposed by Gonçalves et al. (2005), comprises soluble and nonencapsulated mineral nutrients to produce seedlings of native forest species. Initially, basic fertilization was carried out by adding nitrogen fertilizer $\left(150 \mathrm{~g} \mathrm{~m}^{-3} \mathrm{~N}\right.$ using ammonium sulfate), phosphorus fertilizer (300 $\mathrm{g} \mathrm{m}^{-3} \mathrm{P}_{2} \mathrm{O}_{5}$ using triple superphosphate), potassium fertilizer $\left(100 \mathrm{~g} \mathrm{~m}^{-3} \mathrm{~K}_{2} \mathrm{O}\right.$ using potassium chloride), and micronutrients in the form of $150 \mathrm{~g}$ of FTE (Fritted Trace Elements). After 50 days of sowing, cover fertilization was started with a nutrient solution applied to the substrate closest to the stem. For this solution, $200 \mathrm{~g} \mathrm{~N}$ (ammonium sulfate) and $200 \mathrm{~g} \mathrm{~K}_{2} 0$ (potassium chloride) were diluted in $100 \mathrm{~L}$ of water. Fertilizations were performed weekly. Therefore, the recommended monthly amount was divided into four parts.

Table 1 shows that the chemical-physical characterization of the CRF Basacote ${ }^{\circledR}$ Mini $6 \mathrm{M}$ formulation is 13-6-16, with a release time of 5 to 6 months.

Tabela 1. Caracterização químico-física do fertilizante de liberação controlada.

Table 1. Chemical-physical characterization of controlled-release fertilizers.

\begin{tabular}{|c|c|c|c|c|c|c|c|c|c|c|}
\hline $\mathrm{N}$ & $\mathrm{P}_{2} \mathrm{O}_{5}$ & $\mathrm{~K}_{2} \mathrm{O}$ & $\mathrm{Mg}$ & $\mathrm{S}$ & $\mathrm{Fe}$ & $\mathrm{Cu}$ & $\mathrm{Mn}$ & Mo & $\begin{array}{c}\text { Grain } \\
\text { diameter }\end{array}$ & $\begin{array}{c}\text { Weight of } \\
1,000 \text { grains }\end{array}$ \\
\hline ---- & & 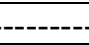 & -ב-.-. & 0 & יניניו- & - & - & ------ & $\mathrm{Mm}$ & $\mathrm{g}$ \\
\hline 13.00 & 6.00 & 16.00 & 1.40 & 10.00 & 0.26 & 0.05 & 0.06 & 0.015 & $1.5-2.5$ & 9.58 \\
\hline
\end{tabular}

FLORESTA, Curitiba, PR, v. 50, n. 3, p. 1613 - 1622, jul/set 2020.

Feletti, T. A. et.al.

ISSN eletrônico 1982-4688

DOI: $10.5380 /$ rf.v50 i3. 65120 
Different doses of fertilizers were added to the commercial substrate (composed of Pinus bark, vermiculite, agro-industrial organic waste (Class A), wood sawdust, horse bed manure, and NPK, at 55\% humidity) before filling the tubes, ensuring that each treatment received equal amounts of substrate. Samples of the substrate were collected for chemical characterization before implementing the experiment (Table 2), following the methodology of Silva (2009).

Tabela 2. Caracterização químico-física do substrato.

Table 2. Chemical-physical characterization of the substrate.

\begin{tabular}{|c|c|c|c|c|c|c|c|c|}
\hline$\overline{\mathrm{pH}}$ & $\bar{N}$ & $\bar{P}$ & $\bar{K}$ & $\mathrm{Ca}$ & $\mathrm{Mg}$ & $\bar{S}$ & $\overline{\mathrm{CE}}$ & Density \\
\hline$\left(\mathrm{H}_{2} \mathrm{O}\right)$ & --- & - & ---- & $\mathrm{g}^{-1}-\cdot$ & 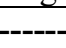 & & $\mathrm{mS} \mathrm{cm}^{-1}$ & $\mathrm{~g} \mathrm{~cm}^{-3}$ \\
\hline 6.2 & 11.5 & 9.0 & 5.2 & 15.0 & 7.2 & 4.5 & 0.4 & 0.35 \\
\hline
\end{tabular}

Sowing was carried out directly in the tubes filled with substrate and their respective doses of fertilizer. Each tube received two seeds, and was covered with a thin layer of the substrate. The tubes were placed in a polypropylene tray on raised beds under a screen with a $50 \%$ reduction in luminous intensity. Irrigation was carried out four times a day, for $7 \mathrm{~min}$, through an automatic irrigation system with microsprinklers with flow rates from 31 to $152 \mathrm{lph}$. After 100 days of sowing, all seedlings were transferred to another area under full sun, receiving daily irrigation four times a day for $10 \mathrm{~min}$.

After 180 days of sowing, the following variables were determined: survival (S, \%); the height of the aerial part $(\mathrm{H}, \mathrm{cm})$, measured from the seedling neck to the insertion of the last leaf with the aid of a graduated ruler; diameter at root collar (DRC, $\mathrm{mm}$ ), measured at the level of the tube edge using a digital caliper; number of leaves (NL), determined by counting the number of visible leaves; leaf chlorophyll content ( $\mathrm{LCC}, \mu \mathrm{g} \mathrm{cm} \mathrm{cm}^{-2}$ ), carried out on samples of intermediate seedling leaves through a portable chlorophyll meter SPAD-502; and the root volume (RV, $\left.\mathrm{cm}^{3}\right)$, obtained using a $500 \mathrm{~mL}$ beaker.

To determine the dry matter of the aerial part (DMAP, g plant ${ }^{-1}$ ), dry matter of the leaves (DML, $\left.\mathrm{g}_{\text {plant }} \mathrm{t}^{-1}\right)$, and root dry matter $\left(\mathrm{RDM}, \mathrm{g}\right.$ plant $\left.\mathrm{t}^{-1}\right)$, four seedlings per repetition were collected randomly, and each was divided into two parts: the aerial part and the root. The root system was separated from the soil by washing it with running water. Next, the material was packed in Kraft paper bags and placed in an oven with forced air circulation at $65^{\circ} \mathrm{C}$ until constant weight, at which point it was weighed on an analytical balance (with a precision of $0.0001 \mathrm{~g}$ ). The total dry matter (TDM, g plant ${ }^{-1}$ ) was the sum of the DMAP and the RDM. After obtaining these values, the Dickson Quality Index (DQI) was determined.

The DML was sent to the laboratory to determine the leaf content of the nutrients $\mathrm{N}, \mathrm{P}, \mathrm{K}, \mathrm{Ca}, \mathrm{Mg}$, $\mathrm{S}, \mathrm{B}, \mathrm{Zn}, \mathrm{Mn}, \mathrm{Fe}$, and $\mathrm{Cu}$, according to Silva (2009). The Diagnosis and Recommendation Integrated System (DRIS) indices and the average nutritional balance indices (NBIm) were also calculated with the aid of the INAF program (Interpretation of Leaf Analysis) (GARCIA, 2013). To calculate the functions of the nutrient ratios, the method proposed by Beaufils (1973) with a k factor of 10 was used. Through the DRIS indices, it was possible to calculate the average nutritional balance index (NBIm), which is the sum of the DRIS indices in the module divided by the number of nutrients involved. The closer the value is to zero, the lower the nutritional imbalance of the plants and, potentially, the higher the production (MALAVOLTA et al., 1997; ARAÚJO et al., 2016).

For the variable $\mathrm{S}(\%)$, the data were subjected to variance analysis, and when checking for significant differences, using the F-test at $5 \%$, the doses were subjected to regression analysis to verify the optimal dose of the CRF through the first derivative estimators $\beta 0$ and $\beta 1$. The generalized mortality of seedlings grown at a CRF dose of $0 \mathrm{~kg} \mathrm{~m}^{-3}$ (control) made it impossible to continue the growth and nutrition assessments of this treatment. For the growth variables, principal component analysis (PCA) was applied to avoid the use of redundant and identical information contained in two or more correlated variables. The most important variable from the data set extracted through multivariate analysis was subjected to univariate analysis of variance. When checking for significant differences, using the 5\% F-test, the treatments were compared by Tukey's test at the 5\% and $1 \%$ probability. The analyses were performed using R Core Team (2018) version 3.5.0. Regression curves between seedling growth and NBIm were also fitted.

\section{RESULTS}

There was an effect $(\mathrm{p} \leq 0.05)$ isolated from the fertilization factor for the survival of P. peroba seedlings at 180 days, according to the analysis of variance. The quadratic model best explained the effect of the CRF doses, with the maximum survival value $(73.47 \%)$ obtained in the $4.91 \mathrm{~kg} \mathrm{~m}^{-3}$ dose (Figure 1). This result was superior to that observed for the CF $(44.79 \%)$ and the control dose $\left(0 \mathrm{~kg} \mathrm{~m}^{-3}\right)$, where seedling survival was not observed.

FLORESTA, Curitiba, PR, v. 50, n. 3, p. 1613 - 1622, jul/set 2020.

Feletti, T. A. et.al.

ISSN eletrônico 1982-4688

DOI: $10.5380 /$ rf.v50 i3. 65120 




Figura 1. Sobrevivência aos 180 dias de mudas de Paratecoma peroba em função do volume do tubete e da adubação com fertilizante de liberação controlada e convencional. I = Adubação convencional (AC); Fertilizante de liberação controlada (FLC).

Figure 1. Survival at 180 days of Paratecoma peroba seedlings produced in tubes of different sizes with variable doses of controlled-release fertilizer and a conventional mineral. I = Conventional mineral fertilizer (AC); Controlled-release fertilizer (FLC).

The relationship between the growth and quality variables of $P$. peroba seedlings as a function of the tube volume and fertilizer dose is shown in Figure 2. The data variability explained on axis $1(83.73 \%)$ and axis $2(9.68 \%)$ totaled $93.41 \%$ of the total data variability. The variables H, DRC, RV, RDM, DMAP, TDM, and DQI were grouped and intuitively correlated. The treatments with tube volumes of 180 and 280 $\mathrm{cm}^{3}$, when associated with the 7.5 dose of CRF, were associated with high values for these variables. TDM showed a greater correlation ( $\mathrm{r}=0.993$ ) with the first main component, and thus it is the variable that best describes the effects of the treatments (Table 3).

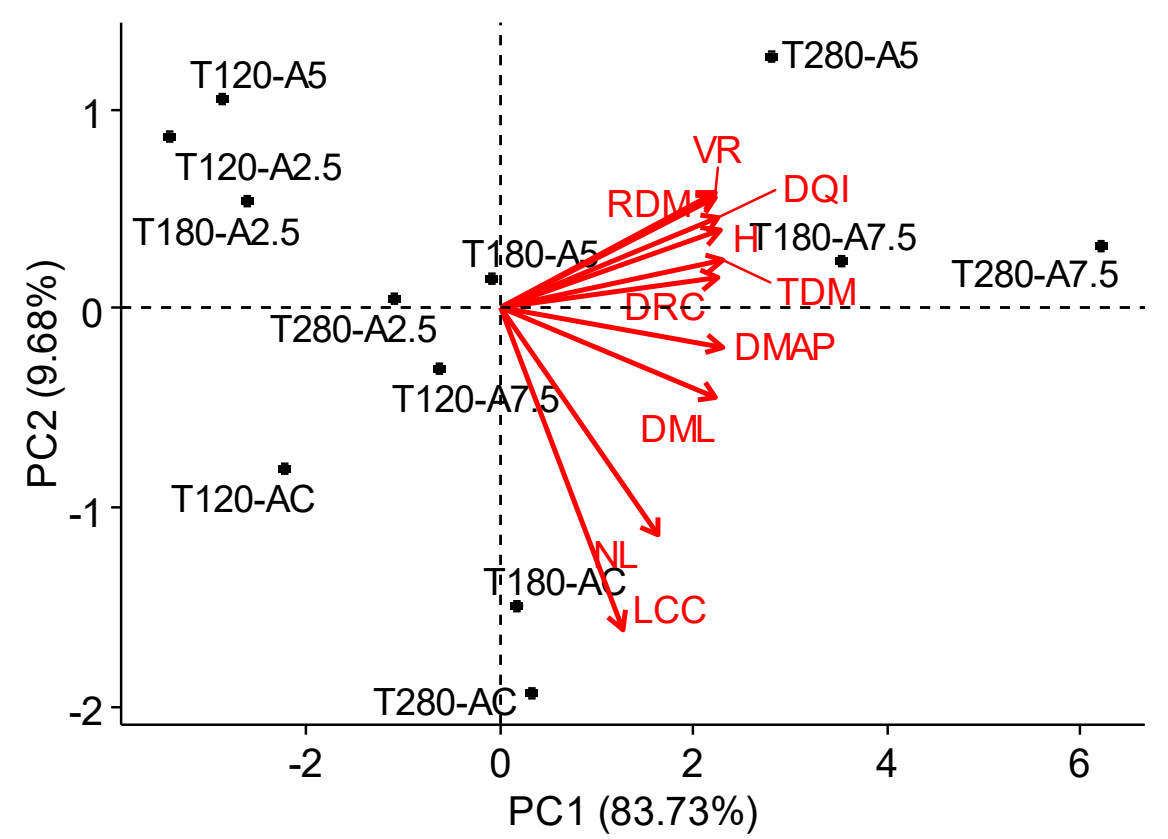

Figura 2. Biplot com as projeções das variáveis relacionadas ao crescimento e qualidade de mudas de Paratecoma peroba em função do volume do tubete e da adubação com fertilizante de liberação controlada e convencional. T: tubete; A: adubação: NF: número de folhas; CF: clorofila foliar; H: altura; DC: diâmetro do coleto; VR: volume da raiz; MSR: massa seca da raiz; MSF: massa seca

FLORESTA, Curitiba, PR, v. 50, n. 3, p. 1613 - 1622, jul/set 2020. 
das folhas; MSPA: massa seca da parte aérea; MST: massa seca total; IQD: índice de qualidade de Díckson.

Figure 2. Biplot with the projections of the variables related to the growth and quality of Paratecoma peroba seedlings produced in tubes of different sizes with variable doses of controlled-release fertilizer and a conventional mineral fertilizer. T: tube; A: fertilization: NF: number of leaves; CF: leaf chlorophyll content; $\mathrm{H}$ : height of the aerial part; CD: diameter at root collar; RV: root volume; MSR: root dry mass; MSF: dry matter of leave; MSPA: dry matter of the aerial part; MST: total dry mass; DQI: Dickson Quality Index.

Tabela 3. Coeficientes de correlação de Pearson entre os escores dos componentes principais e as variáveis de crescimento e qualidade de mudas de Paratecoma peroba.

Table 3. Pearson correlation coefficients between the scores of the main components and the growth and quality variables of Paratecoma peroba seedlings.

\begin{tabular}{lll}
\hline Variables & PC1 & PC2 \\
\hline Number of leaves (NL) & 0.708 & 0.492 \\
Height of the aerial part (H) & 0.980 & -0.165 \\
Diameter at root collar (DRC) & 0.972 & -0.066 \\
Leaf chlorophyll content (LCC) & 0.543 & 0.694 \\
Root volume (RV) & 0.959 & -0.248 \\
Dry matter of the aerial part (DMAP) & 0.988 & 0.082 \\
Dry matter of leave (DML) & 0.964 & 0.189 \\
Root dry mass (RDM) & 0.959 & -0.241 \\
Total dry mass (TDM) & $\mathbf{0 . 9 9 3}$ & -0.102 \\
Dickson Quality Index (DQI) & 0.971 & -0.198 \\
\hline
\end{tabular}

PC: Main components.

There was a significant interaction $(\mathrm{p}<0.01)$ between tube volume and fertilization with CRF and CF for the MST of $P$. peroba seedlings (Figure 3). The joint use of the CRF at a dose of $7.5 \mathrm{~kg} \cdot \mathrm{m}^{-3} \mathrm{and} \mathrm{a}$ $280 \mathrm{~cm}^{3}$ tube promoted the greatest production of TDM $\left(8.41 \mathrm{~g} \mathrm{plant}^{-1}\right)$ from $P$. peroba seedlings after 180 days.



Figura 3. Massa seca total (MST) de mudas de Paratecoma peroba, aos 180 dias, em função do volume do tubete e da adubação com fertilizante de liberação controlada e convencional. I = Desvio padrão; Letras maiúsculas comparam os volumes de tubete dentro de cada dose, pelo teste de Tukey $(\mathrm{p} \leq$ $0,05)$. Letras minúsculas comparam as doses dentro de um mesmo volume.

Figure 3. Total dry mass (MST) of Paratecoma peroba seedlings at 180 days produced in tubes of different sizes with variable doses of controlled-release fertilizer and a conventional mineral fertilizer. $\mathrm{I}=$ standard deviation; Upper case letters compare the tube volumes within each dose, by the Tukey test $(\mathrm{p} \leq 0.05)$. Lowercase letters compare the doses within a same volume.

According to the data on the nutritional status of $P$. peroba seedlings described in Table 4 , there was variation in the DRIS indices according to the factors analyzed. The closer the DRIS indices were to

FLORESTA, Curitiba, PR, v. 50, n. 3, p. 1613 - 1622, jul/set 2020. 
zero, the closer to nutritional balance the $P$. peroba seedlings were. Concerning the NBIm, it was observed that fertilization with CRF at a dose of $7.5 \mathrm{~kg} \mathrm{~m}^{-3}$ combined with 180 and $280 \mathrm{~cm}^{3}$ tubes promoted more nutritionally-balanced seedlings.

Tabela 4. Teor de nutrientes nas folhas (TN), índice DRIS (ID) e índice de balanço nutricional médio (IBNm) geradas a partir das normas DRIS para mudas de Paratecoma peroba em função do volume do tubete e da adubação com fertilizante de liberação controlada e adubação convencional.

Table 4. Leaf nutrient content (TN), DRIS index (ID) and average nutrient balance index (IBNm) generated from the DRIS standards for Paratecoma peroba seedlings at 180 days, produced in tubes of different sizes with variable doses of controlled-release fertilizer (CRF) and a conventional mineral fertilizer $(\mathrm{CF})$.

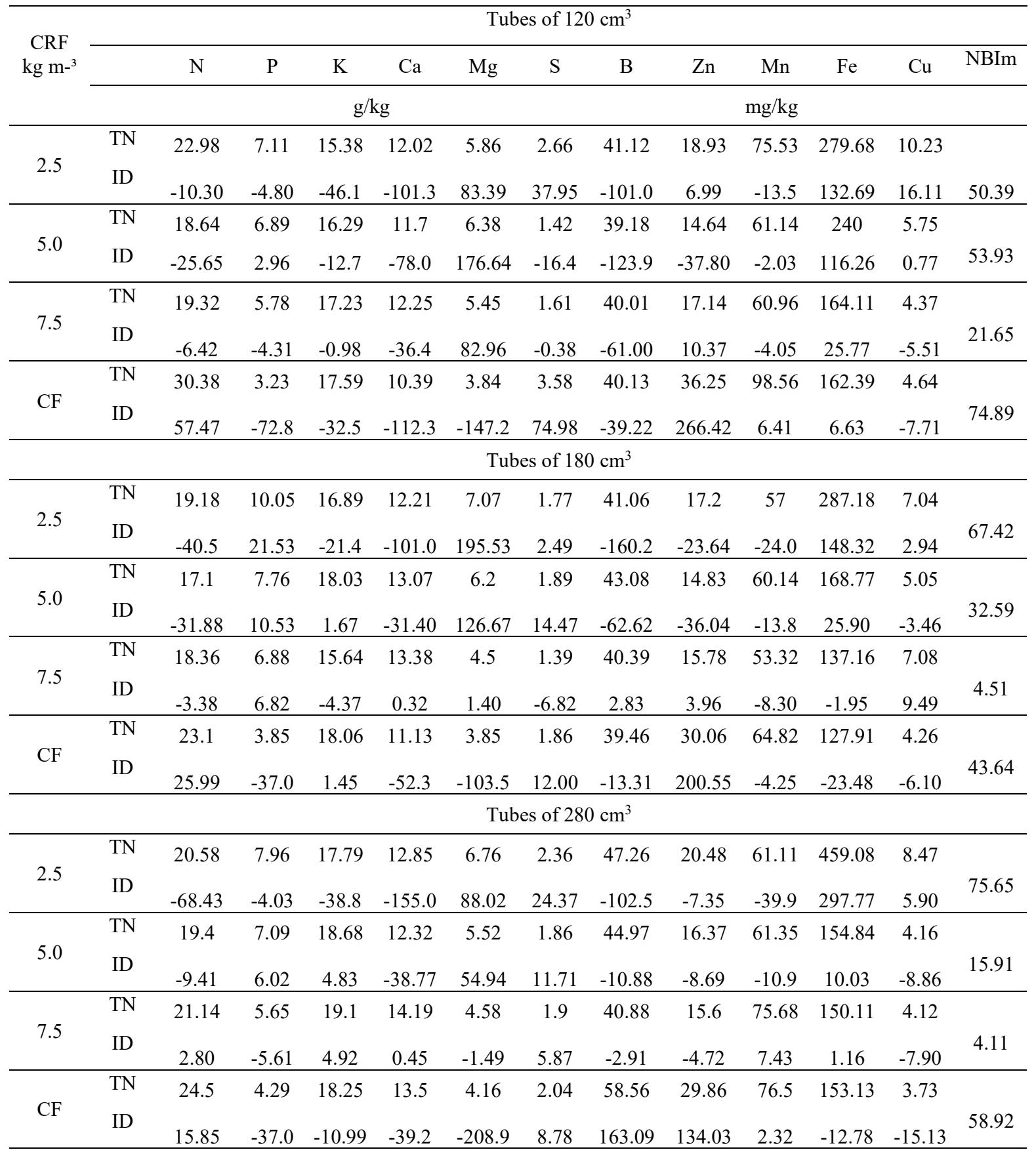

The results of the regression analysis between NBIm and TDM. which was the variable that best described the growth of $P$. peroba seedlings. are shown in Figure 4.

FLORESTA, Curitiba, PR, v. 50, n. 3, p. 1613 - 1622, jul/set 2020. 


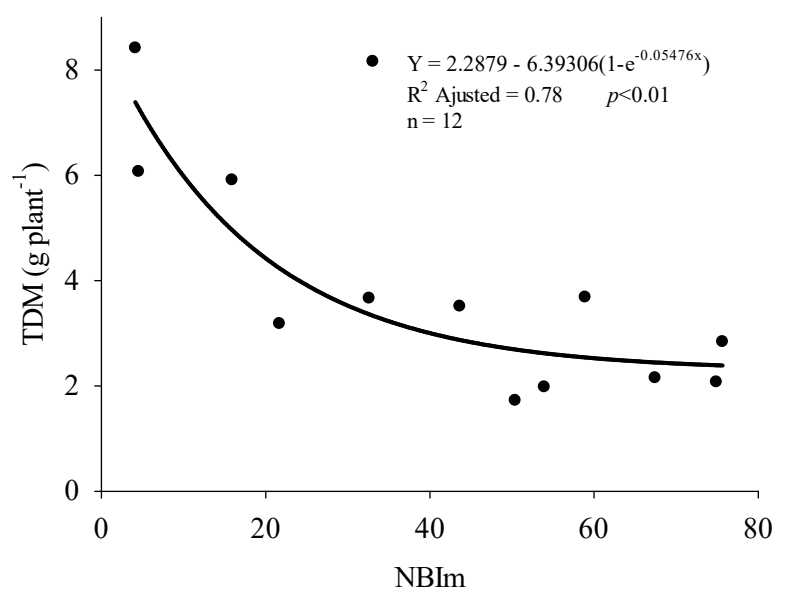

Figura 4. Relação entre o Índice de Balanço Nutricional médio (IBNm) e produção de Massa seca total (MST) de mudas de Paratecoma peroba.

Figure 4. Relationship between the mean Nutrient Balance Index (IBNm) and Total dry mass (MST) production of Paratecoma peroba seedlings.

\section{DISCUSSION}

Fertilization with CRF. among the factors tested. was crucial for the survival of seedlings of $P$. peroba. which were nutritionally demanding in the nursery phase. The high mortality rate of seedlings in the control treatment may be related to the ecophysiological characteristics of the species. Late secondary species show slower growth and a longer nursery time. requiring continuous fertilization during this period. Alternatively. the 80-day period with full sun exposure may have contributed to the increase in mortality in the poorly developed and poorly nourished seedlings from the control treatment.

Through analysis of the main components (Figure 1; Table 3). it was possible to identify that TDM acts directly with the variables H. DRC. RV. RDM. DMAP. and DQI. This is because they act with the same signal as CP1; that is. when the value of one increase. the value of the other increases (multicollinearity). TDM was the variable that presented the greatest discriminatory power in CP1. and therefore. was the most important variable to describe and select $P$. peroba seedlings with superior growth and/or morphological quality.

The growth and quality of seedlings can be better described using the dry mass production variable of the root. the aerial part. and the combined total (FERNANDES et al. 2019). According to Larcher (2006). the difference between carbon gains via photosynthesis and losses via respiration $\left(\mathrm{CO}_{2}\right.$ balance) results in vegetative growth; thus. the carbon not consumed in the respiratory process increases the dry mass of the plant. Therefore. it is believed that the higher the value of MST. the better the quality of the seedlings. and the better the survival and growth of plants after transplantation in the field.

In general. the cultivation of $P$. peroba seedlings were possible regardless of the size of tube used. However. among the treatments tested. the CRF combination at the dose of $7.5 \mathrm{~kg} \mathrm{~m}^{-3}$ with the $280 \mathrm{~cm}^{3}$ tube proved to be the most effective for production of seedlings with maximum morphological quality (Figure 2;3). The higher production of TDM in these treatments may be attributed to the synergistic action of improving the nutritional status of the plant and using larger tubes. which may include a greater absolute amount of substrate and fertilizer. as well as a greater available space for growth and nutrient exploration of the roots.

Previous literature suggests that forest species. independent of the ecological group. are responsive to the addition of CRF to the substrate. Navroski et al. (2016) demonstrated that Cedrela fissilis seedlings (late secondary) showed good growth when $5 \mathrm{~kg} \mathrm{~m}^{-3}$ of CRF was incorporated into the substrate. In seedlings of Peltophorum dubium (pioneer). Dutra et al. (2016) found growth improvement when they used $\mathrm{CRF}$ at doses between 5.4 and $8.2 \mathrm{~kg} \mathrm{~m}^{-3}$. In addition. Rossa et al. (2015) found that CRF led to growth gains in seedlings of Anadenanthera peregrina (initial secondary) at doses of 5.54 to $6.68 \mathrm{~kg} \cdot \mathrm{m}^{-3}$ and Schinus terebinthifolius (pioneer) at doses of 8.38 to $14.42 \mathrm{~kg} \cdot \mathrm{m}^{-3}$. Moraes Neto et al. (2003) experimented with 5 native species. such as Myroxylon peruiferum (climax). and found that doses between 3.2 and $4.8 \mathrm{~kg} \mathrm{~m}^{-3}$ of CRF led to the formation of quality seedlings in all 5 species. Research on the timing of seedling production indicates that the pioneer species stabilized in growth earlier (90 days) than the non-

FLORESTA, Curitiba, PR, v. 50, n. 3, p. 1613 - 1622, jul/set 2020. 
pioneer species (150 to 180 days). Therefore. studies are needed to establish optimal CRF doses and formulations with adequate release times for each cultivated species.

In Calophyllum brasiliense and Toona ciliata. Lisboa et al. (2012) analyzed three tube volumes (115. 180. and $280 \mathrm{~cm}^{3}$ ) and concluded that the most suitable tubes for C. brasiliense and T. ciliata were $180 \mathrm{~cm}^{3}$ and $280 \mathrm{~cm}^{3}$. respectively. Gasparin et al. (2014) found that the use of the $280 \mathrm{~cm}^{3}$ tube provided superior growth of Cabralea canjerana seedlings in the field phase. Melo et al. (2018) analyzed the influence of tube volume (30. 55. 110. 180. and $280 \mathrm{~cm}^{3}$ ) on the seedling growth of Mimosa caesalpiniifolia (pioneer) in the nursery and in the field. They found that. although the seedlings produced in the three larger volume containers showed greater growth in the nursery phase. this difference tended to disappear after implantation in the field. making it possible to produce seedlings of this species in any of the tested containers.

Thus. while larger tubes may result in larger seedlings. they require more space. substrate. and investment. By contrast. small containers are easy to handle and require less space and substrate; however. they can limit the growth of seedlings with a longer production cycle. nullifying and/or limiting the effect of fertilizers and. consequently. the nutritional balance of the seedlings. Brachtvogel and Malavasi (2010) found that the NL. DMAP. and TDM of Peltophorum dubium seedlings were similar under fertilization with NPK. regardless of the volume of the container. which did not occur in those under CRF. in which the growth was lower with the decrease in container volume.

Gasparin et al. (2015) analyzed the combined effect of CRF doses (0.3. 6. 9. and $\left.12 \mathrm{~kg} \mathrm{~m}^{-3}\right)$ on the growth and nutrition of Parapiptadenia rigida seedlings in the nursery with different tube volumes $(50$. 110. and $180 \mathrm{~cm}^{3}$ ). They found that as the seedlings were exposed to higher doses of CRF. a higher $\mathrm{N}$ content was observed in the DMAP. However. no positive effect on seedling growth was observed on doses above $9.0 \mathrm{~kg} \cdot \mathrm{m}^{-3}$. Concerning the container volume. the seedlings grown in $180 \mathrm{~cm}^{3}$ containers showed $\mathrm{P}$. K. Mg. and S.

Conventional fertilization by Gonçalves et al. (2005) of native nursery seedlings was not effective for $P$. peroba seedlings when compared to CRF fertilization. possibly due to the absence of $\mathrm{Mg}$. This can be seen in Table 4. where the Mg values and their respective DRIS indices were excessively low. It is also important to note that the $\mathrm{Zn}$ contents presented very high DRIS index values. The DRIS Ca and B indexes were excessively low in the treatments with $120 \mathrm{~cm}^{3}$ tubes and CRF treatments at a dose of $2.5 \mathrm{~kg} \mathrm{~m}^{-3}$. The levels of $\mathrm{N}$ in the DML of seedlings treated with conventional fertilization were slightly higher than those of seedlings cultivated with CRF. which was not reflected in gains in MST production.

Analysis of the nutritional status of $P$. peroba seedlings using NBIm revealed that the production of TDM was significantly associated with the nutritional status of the plants $\left(\mathrm{R}^{2}=0.66 ; \mathrm{p}<0.01\right)$. These results are compatible with the theoretical model suggested by Beaufils (1973). in which low values of NBIm. indicative of plants with balanced nutrition. mostly corresponded to samples with high production. confirming the importance of nutritional balance for the growth of $P$. peroba seedlings.

\section{CONCLUSION}

- The gains in growth and nutritional balance of Paratecoma peroba seedlings grown in higher CRF doses are limited when using tubes with volumes of 120 and $180 \mathrm{~cm}^{3}$.

- Paratecoma peroba seedlings produced in a $280 \mathrm{~cm}^{3}$ tube with a $7.5 \mathrm{~kg} \mathrm{~m}^{-3}$ dose of CRF can be considered suitable for planting in the field.

\section{ACKNOWLEDGEMENTS}

The present work was carried out with the support of Coordenação de Aperfeiçoamento de Pessoal de Nível Superior - Brasil (CAPES); Fundação de Amparo à Pesquisa e Inovação do Espírito Santo (FAPES).

\section{REFERENCES}

ARAÚJO. E. F.; SANTANA ARAUCO. A. M.; JESÚS LACERDA. J. J.; RATKE. R. F.; MEDEIROS. J. C. Crescimento e balanço nutricional de mudas de Enterolobium contortsiliquum com aplicação de substratos orgânicos e água residuária. Pesquisa Florestal Brasileira. Colombo. v. 36. n. 86. p. 169-177. 2016.

BEAUFILS. E. R. Diagnosis and recommendation integrated system (DRIS). Soil Science Bulletin. Natal. n. 1. p. 1-132. 1973.

FLORESTA, Curitiba, PR, v. 50, n. 3, p. 1613 - 1622, jul/set 2020. 
BRACHTVOGEL. E. L.; MALAVASI. U. C. Volume do recipiente. adubação e sua forma de mistura ao substrato no crescimento inicial de Peltophorum dubium (Sprengel) Taubert em viveiro. Revista Árvore. Viçosa. v. 34. n. 2. p. 223-232. 2010.

CANABRAVA LISBOA. A.; DOS SANTOS. P. S.; OLIVEIRA NETO. S. N.; NUNES DE CASTRO. D.; MARQUES DE ABREU. A. H. Efeito do volume de tubetes na produção de mudas de Calophyllum brasiliense e Toona ciliata. Revista Árvore. Viçosa. v. 36. n. 4. p. 603-609. 2012.

CENTRO NACIONAL DE CONSERVAÇÂO DA FLORA - CNCFlora. Paratecoma peroba in Lista Vermelha da flora brasileira versão 2012.2. Disponível em <http://cncflora.jbrj.gov.br/portal/ptbr/profile/Paratecoma peroba>. Acesso em: 25 jan 2019.

DUTRA. T. R.; MASSAD. M. D.; SARMENTO. M. F. Q.; MATOS. P. S.; OLIVEIRA. J. C. Fertilizante de liberação lenta no crescimento e qualidade de mudas de canafístula (Peltophorum dubium (Spreng.) Taub.). Floresta. Curitiba. v. 46. n. 4. p. 491-498. 2016.

FERNANDES. M. M.; SOUSA. F. L.; SILVA. J. P. M.; ARAÚUJ. E. F.; FERNANDES. M. R. M.; NÓBREGA. R. S. A. Redes Neurais Artificiais na estimação de variáveis biométricas de mudas de espécies florestais produzidas em diferentes substratos. Revista de Ciências Agroveterinárias. Lages. v. 18. n. 1. p. 47-58. 2019

GARCIA. M. B. INAF: software para interpretação de análise foliar. 2013.

GASPARIN. E.; ARAUJO. M. M.; SALDANHA. C. W.; TOLFO. C. V. Controlled release fertilizer and container volumes in the production of Parapiptadenia rigida (Benth.) Brenan seedlings. Acta Scientiarum. Agronomy. Maringá. v. 37. n. 4. p. 473-481. 2015.

GASPARIN. E.; DE AVILA. A. L.; ARAUJO. M. M.; CARGNELUTTI FILHO. A.; DORNELES. D. U.; FOLTZ. D. R. B. Influência do substrato e do volume de recipiente na qualidade das mudas de Cabralea canjerana (Vell.) Mart. em viveiro e no campo. Ciência Florestal. Santa Maria. v. 24. n. 3. p. 553-563. 2014.

GONÇALVES. J. L. de M. SANTARELli. E. G. MORAES NETO. S. P. MANARA. M. P. Produção de mudas de espécies nativas: substrato. nutrição. sombreamento e fertilização. In: GONÇALVES. J. L de M. \& BENEDETTI. V. Nutrição e fertilização florestal. Instituto de Pesquisa e Estudos Florestais. Piracicaba. SP. p. 309- 350. 2005.

IRFAN. S. A.; RAZALI. R.; KUSHAARI. K.; MANSOR. N.; AZEEM. B.; VERSYPT. A. N. F. A review of mathematical modeling and simulation of controlled-release fertilizers. Journal of Controlled Release. Amsterdam. v. 271. n. 10. p. 45-54. 2018.

LARCHER W. 2006. Ecofisiologia vegetal. 2.ed. São Carlos: Rima Artes e Textos. 550 p.

LINS. B. L. A.; NASCIMENTO. M. T. Fenologia de Paratecoma peroba (Bignoniaceae) em uma floresta estacional semidecidual do norte fluminense. Brasil. Revista Rodriguésia. Rio de Janeiro. Brasil. v.61. n.3. p.559-568. 2010.

LORENZI. H. Árvores brasileiras: manual de identificação e cultivo de plantas arbóreas nativas do Brasil. Nova Odessa: Plantarum. 368 p. 2009.

MALAVOLTA. E.; VITTI. G. C.; OLIVEIRA. S. A. Princípios. métodos e técnicas de avaliação do estado nutricional. In: MALAVOLTA. E.. ed. Avaliação do estado nutricional de plantas: Princípios e aplicações. 2.ed. Piracicaba. Potafos. 1997. p.115-230.

MELO. L. A.; ABREU. A. H. M.; SANTOS LELES. P. S.; OLIVEIRA. R. R.; SILVA. D. T. Qualidade e crescimento inicial de mudas de Mimosa caesalpiniifolia Benth. produzidas em diferentes volumes de recipientes. Ciência Florestal. Santa Maria. v. 28. n. 1. p. 47-55. 2018.

MORAES NETO. S. P.; MORAES GONÇALVES. J. L.; RODRIGUES. C. J.; LUIZ. W.; AZEVEDO GERES. F. D.; AGUIRRE JR. J. H. Produção de mudas de espécies arbóreas nativas com combinações de adubos de liberação controlada e prontamente solúveis. Revista Árvore. Viçosa. v. 27. n. 6. p. 779-789. 2003.

NAVROSKI. M. C.; TONETT. E. L.; MAZZO. M. V.; FRIGOTTO. T.; OLIVEIRA PEREIRA. M.; GALVANI. L. V. Procedência e adubação no crescimento inicial de mudas de cedro. Pesquisa Florestal Brasileira. Colombo. v. 36. n. 85. p. 17-24. 2016.

FLORESTA, Curitiba, PR, v. 50, n. 3, p. 1613 - 1622, jul/set 2020

Feletti, T. A. et.al.

ISSN eletrônico 1982-4688

DOI: 10.5380/rf.v50 i3. 65120 
R DEVELOPMENT CORE TEAM. R: a language and environment for statistical computing. Vienna. Austria: R Foundation for Statistical Computing. 2011. Disponível em: <http://www.R-project.org/>. Acesso em: 15 dez 2018.

ROSSA. Ü. B.; ANGElO. A. C.; WESTPHAlEN. D. J.; OLIVEIRA. F. E. M.; DA SILVA. F. F.; ARAUJO. J. C. Fertilizante de liberação lenta no desenvolvimento de mudas de Anadenanthera peregrina (L.) Speg.(angico-vermelho) e Schinus terebinthifolius Raddi (aroeira-vermelha). Ciência Florestal. Santa Maria. v. 25. n. 4. p. 841-852. 2015.

SILVA. F. C. D. A. S. Manual de análises químicas de solos. plantas e fertilizantes. 2. ed. Brasília. DF: Embrapa Informação Tecnológica. 2009. 627 p.

WALWORTH. J. L.; SUMMER. M. E.; ISAAC. R. A.; PLANK. C. O. Preliminary DRIS norms for alfalfa in the southeastern United States and a comparison with midwestern norms. Agronomy Journal. Madison. v. 78. n. 6. p. 1046-1052. 1986. 